\title{
Microorganism inactivation by an ozonation step optimized for micropollutant removal from tertiary effluent
}

\author{
H. Schaar*, R. Sommer**, R. Schürhagl**, P. Yillia* and N. Kreuzinger* \\ * Institute of Water Quality, Resources and Waste Management, Vienna University of Technology, Karlsplatz 13/226, \\ 1040 Vienna, Austria \\ ** Medical University Vienna, Institute for Hygiene and Applied Immunology, Water Hygiene, Kinderspitalgasse 15, \\ 1095 Vienna, Austria
}

^Corresponding author: hschaar@iwaq.tuwien.ac.at

Short title: Microorganism inactivation by an ozonation step

\begin{abstract}
This paper demonstrates the additional benefit of the microbicidal efficacy of an ozonation plant implemented for micropollutant removal from tertiary effluent. Due to the low amount of viruses and protozoa in the tertiary effluent, bacteriophage MS2 and spores of Bacillus subtilis were dosed as surrogates. At specific ozone consumptions of 0.6 and $0.9 \mathrm{~g} \mathrm{O}_{3} / \mathrm{g}$ DOC a 2-log CFU reduction was achieved for indigenous Escherichia coli and enterococci and the limits of the European bathing water directive for the excellent quality of inland waters were met. Higher removal was impeded by the shielding effect of suspended solids in the effluent, which implies the combination of ozonation with a preceding filtration step if higher microbicidal performances are required. The surrogate virus MS2 was reduced by 4-5 log while no significant inactivation was detected for $B$. subtilis spores. Additionally, the impact of ozonation on the biochemical oxygen demand (BOD) was studied. The BOD 5 measurement was not adversely affected despite the reduced concentration of microorganisms after ozonation. The intrinsic increase in $\mathrm{BOD}_{5}$ averaged $15 \%$ at $0.6-0.7 \mathrm{~g} \mathrm{O}_{3} / \mathrm{g}$ DOC. The impact of the projected increase on the surface water quality is generally not considered a problem but has to be assessed on a case-by-case approach.
\end{abstract}

Key words | Bacillus subtilis spores, bacterial fecal indicators, bacteriophage MS2, biological oxygen demand ozonation, tertiary effluent

\section{INTRODUCTION}

As a consequence of climate change and the intensification of the urban water cycle due to urbanization, reuse of wastewater treatment plant effluent gains more relevance (UNEP \& GEC 2005; Oneby et al. 2010; Gerrity et al. 2011). Microbial and hygienic aspects are relevant to both the use of water resources for human demands (bathing water, irrigation, and drinking water supply) and the environment. As wastewater - even after treatment - is a significant source of pathogenic microorganisms in the aquatic environment, their inactivation in the effluent of wastewater treatment plants is becoming more important (WHO 2006a, 2006b).

Disinfecting wastewater is not a novelty (Rice et al. 1981; Chrtek \& Popp 1991; Paraskeva \& Graham 2002); it is commonly applied in countries such as the USA, Japan, Australia (Loeb

CIWA Publishing [2013]. The definitive peer-reviewed and edited version of this article is published in Water Science \& Technology, Volume 68, Issue 2, 311-318, 2013, https://doi.org/10.2166/wst.2013.212 and is available at www.iwapublishing.com. This is the accepted version. 
et al. 2012) and (semi-)arid areas where the wastewater is directly or indirectly reused (Almadani et al. 2000; Martinez et al. 2011).

Recently, the application of ozone or activated carbon as advanced treatment steps for micropollutant removal from treated effluent is under discussion (Gerrity et al. 2011; Gruenebaum et al. 2011; Zimmermann et al. 2011). In addition to the suitability of ozone for micropollutant removal (Bahr et al. 2005; Hollender et al. 2009; Schaar et al. 2010) the disinfection potential of ozone for advanced wastewater treatment could offer the additional benefit of microorganism inactivation (Oneby et al. 2010). In order to assess this beneficial effect there is a need to obtain more data on the inactivation of microorganisms under operational conditions applied for the removal of micropollutants (Hollender et al. 2009; Schaar et al. 2010). According to these needs the performance of an ozonation pilot plant (Schaar et al. 2010) was evaluated: 1) by means of the inactivation of dosed challenge microorganisms; and 2) the indigenous fecal bacteria Escherichia coli and enterococci as bacteriological parameters of the European bathing water directive (Directive 2006/7/EC).

As surrogate for viruses, bacteriophage MS 2 was chosen because of its similarity in size and shape to human enteric viruses (Anonymous, 1991). Spores of Bacillus subtilis have been found to be of value for testing the ozone inactivation of Giardia lamblia cysts and Cryptosporidium parvum oocysts (Facile et al. 2000).

A second aspect in relation to microbial activity of ozonated wastewater targeted in this paper is the impact of ozonation on the BOD (biochemical oxygen demand). The BOD is one of the traditional parameters regulated in emission standards of wastewater treatment plants and a key parameter for surface water quality characteristics (Uhlmann \& Horn 2001; Wiesmann et al. 2007). First, the reduced concentration of microorganisms can result in an underestimation of the BOD due to the lack of organisms consuming oxygen during the measurement and second, the BOD can increase due to the cleavage of recalcitrant organic matter by ozone, i.e. the transformation to more biodegradable substances. This may have a decisive effect on surface water quality, especially in the case of diminishing water flow due to climate change.

Hence, the present paper will deal with the following aspects:

- microbicidal efficacy of the pilot ozonation plant regarding indicator bacteria and surrogates for viruses and protozoa;

- the applicability of two established BOD-methods for ozonized effluent samples to assess the impact of ozonation on the measurement principle;

- the increase of biodegradability of recalcitrant organic substances on the basis of $\mathrm{BOD}_{5-}$ measurements.

\section{MATERIALS AND METHODS}

\section{Ozonation pilot plant}

The effect of ozonation on the inactivation of microorganisms in the effluent of a wastewater treatment plant (WWTP) was assessed at an ozonation pilot plant for micropollutant removal (Schaar et al. 2010). The pilot plant was installed at a municipal WWTP operated according to the best available technology, i.e. biological nitrogen removal. A side stream of the WWTP effluent (30-36 $\mathrm{m}^{3} / \mathrm{h}$ ) was used as the influent to the ozonation plant. The pilot plant consisted of the ozonation unit (ozone generator by Wedeco, type SOM 7 with a production capacity of

CIWA Publishing [2013]. The definitive peer-reviewed and edited version of this article is published in Water Science \& Technology, Volume 68, Issue 2, 311-318, 2013, https://doi.org/10.2166/wst.2013.212 and is available at www.iwapublishing.com. This is the accepted version. 
$1 \mathrm{~kg} \mathrm{O}_{3} / \mathrm{h}$, ozone destruction unit for offgas and liquid oxygen storage tank for feed gas supply) and two CSTRs with a working volume of $5 \mathrm{~m}^{3}$ each, operated in series. Ozone was supplied to the first reactor with diffusor plates, the second tank acted as a reaction unit. More detailed information is documented by Schaar et al. (2010).

Samples were collected from the effluent of the WWTP (corresponding to the influent of the pilot plant, $\mathrm{O}_{3}$ in), the effluent of the first CSTR (R1 out) and the effluent of the second CSTR (corresponding to the effluent of the ozonation pilot plant, R2 out). The sampling points are depicted in Figure 1.

\section{Inactivation experiments}

Preliminary measurements revealed low concentrations of viruses and protozoa in contrast to indigenous E. coli and enterococci. To provide representative results on the microbicidal efficacy of the ozonation plant with respect to the inactivation of viruses and protozoa, it was decided to continuously dose surrogates. A suspension with the two surrogate organisms was proportionally added to the influent of the ozonation plant by means of a peristaltic pump (see Figure 1) in order to achieve a concentration of approximately $10^{6}$ per $\mathrm{mL}$ for bacteriophages MS2 and $10^{6}$ per $100 \mathrm{~mL}$ for $B$. subtilis spores. A static mixer guaranteed a homogenous dispersion of the test organisms.

The specific ozone consumption, $Z_{\text {spec }}$, for the two sampling campaigns was 0.6 and $0.9 \mathrm{~g} \mathrm{O}_{3} / \mathrm{g}$ DOC, respectively, with a corresponding transferred ozone dose of 5 and $7 \mathrm{mg} / \mathrm{L}$. The ozone concentration in the effluent of the first reactor was 0.2 and $0.9 \mathrm{mg} \mathrm{O}_{3} / \mathrm{L}$, no residual ozone was measured in the effluent of the second reactor. The $\mathrm{pH}$ in the WWTP effluent was neutral and the total hydraulic retention time in the pilot plant ranged between 16 and 20 min. More details on the wastewater characteristics and process conditions are given in Schaar et al. (2010).

\section{BOD experiments}

One of the motivations for the BOD experiments was the evaluation of standard methods for BOD measurements in order to exclude any falsification of the BOD results due to the reduction of microorganisms.

The measurements were carried out with the manometric method (OxiTop $\left.{ }^{\circledR}, \mathrm{WTW}\right)$ and the method for undiluted samples (EN 1899-2).

The manometric measurement (OxiTop ${ }^{\circledR}$, WTW) is based on the indirect measurement of the oxygen consumption in the sample. The BOD is determined by the pressure drop in the gas phase (differential measurement), i.e. the oxygen is consumed by microorganisms in the sample and the produced $\mathrm{CO}_{2}$ in the gas phase is absorbed by $\mathrm{KOH}$, which results in a negative pressure.

The method with undiluted samples (EN 1899-2) is based on respirometry, i.e. the oxygen demand during a certain period is determined by measuring the $\mathrm{O}_{2}$-concentration at the beginning and at the end of the incubation period.

CIWA Publishing [2013]. The definitive peer-reviewed and edited version of this article is published in Water Science \& Technology, Volume 68, Issue 2, 311-318, 2013, https://doi.org/10.2166/wst.2013.212 and is available at www.iwapublishing.com. This is the accepted version. 


\section{Microbiological analyses}

Two independent test series were performed.

Samples were taken in sterile 1-lL bottles containing sodium thiosulphate $(1 \mathrm{~mL}$ of a $10 \% \mathrm{w} / \mathrm{vol}$ solution per bottle) in order to quench ozone if present in the sample. The samples were analysed in triplicate according to standard methods.

\section{Indigenous fecal bacteria}

Detection and enumeration of E. coli and enterococci were determined according to the ISO standards 9308-3 and ISO 7899-2, respectively.

\section{Challenge microorganims}

Bacteriophage. MS2 (F+ specific, single-stranded RNA virus, Leviviridae): propagation and enumeration according to ISO 10705-1; host bacterium Salmonella typhimurium WG 49. Before use the phage stock solutions were filtered through a $0.2 \mu \mathrm{m}$ membrane (Millex-GV, Millipore).

Spores of Bacillus subtilis ATCC 6633: spores were produced in liquid enrichment medium, heated at $80^{\circ} \mathrm{C}$ for $10 \mathrm{~min}$, washed by centrifugation, and suspended in sterile distilled water (Sommer \& Cabaj 1993). The enumeration as CFU was performed by pour plating with plate count agar (CM 325, Oxoid; $37^{\circ} \mathrm{C} / 48$ h).

The concentrations of the microorganisms were transformed to $\log 10$ and the reductions $\log$ $\left(\mathrm{N} / \mathrm{N}_{0}\right)$ were calculated from the concentrations before $\left(\log -\mathrm{N}_{0}\right)$ and after treatment $(\log -\mathrm{N})$.

\section{Heterotrophic plate counts}

Heterotrophic plate counts (HPC) for the BOD experiments were conducted according to ISO 6222:1999. Sterile Scott bottles (500 mL), previously autoclaved at $121{ }^{\circ} \mathrm{C}$ for $15 \mathrm{~min}$ and allowed to cool at room temperature, were used to collect water samples to detect Heterotrophic Plate Count (HPC) bacteria. Samples were stored on ice packs in a cooling box and processed in the laboratory within 8 hours of collecting the first sample. The pour plate technique was used for the determination of HPC bacteria. For each sample, three appropriate dilutions were prepared. The dilutions were based on the presumptive bacteria density of each sample prior to the determination. One $\mathrm{mL}$ of each of the appropriate dilutions was then placed onto petri dishes, which were in triplicates, for each dilution. Immediately, the nutrient rich media, Yeast Extract Agar (ISO 6222:1999), which had been prepared under sterile conditions, was poured aseptically on the processed samples in the petri dishes and mixed by swirling gently. The mixture was then allowed to solidify for $10-15 \mathrm{~min}$ and incubated at $37^{\circ} \mathrm{C}$ for 48 hours. For optimum accuracy of the plate count results, all the petri dishes (plates) with 30-300 colony forming units (CFU), i.e. the preferred range for total CFU/plate, were counted and recorded as CFU per ml after incubation.

\section{Life/dead staining}

The LIVE/DEAD® BacLight ${ }^{\mathrm{TM}}$ Bacterial Viability Kit (Molecular Probes ${ }^{\circledR}$ ) provides two different fluorescence dyes to rapidly distinguish between live bacteria with intact plasma membranes and dead bacteria with compromised membranes. SYTO ${ }^{\circledR} 9$ labels live bacteria with green fluorescence whereas propidium iodide labels membrane-compromised bacteria with red fluorescence.

CIWA Publishing [2013]. The definitive peer-reviewed and edited version of this article is published in Water Science \& Technology, Volume 68, Issue 2, 311-318, 2013, https://doi.org/10.2166/wst.2013.212 and is available at www.iwapublishing.com. This is the accepted version. 


\section{RESULTS AND DISCUSSION}

\section{Inactivation experiments}

The microbicidal performance of the ozonation plant for micropollutant removal is depicted in Figure 2. The corresponding log concentrations in the influent and the effluent of the two pilot plant reactors operated in series are given in Table 1.

The inactivation of indigenous $E$. coli was in the same range (approx. 2-log reduction) for both specific ozone consumptions, while a slight decrease in the inactivation performance with increasing ozone dose was observed for enterococci. This lack of correlation between the inactivation and the specific ozone consumption has also been observed by Zimmermann et al. (2011), who determined a reduction between 1.5 and 3 log units for specific ozone doses from 0.4 to $1.2 \mathrm{~g} \mathrm{O}_{3} / \mathrm{g}$ DOC.

A higher degree of inactivation could not be achieved due to commonly occurring suspended solids in wastewater treatment plant effluent. Ozone is not penetrating particles and hence, bacteria inside the flocs were protected. This was confirmed by the results of the Life/Dead staining, see Figure 3. The shielding effect of suspended solids was reported previously by Janex et al. (2000) and Xu et al. (2002) who found a higher log reduction for fecal coliforms, enterococci and $E$. coli in filtered effluent. To investigate if shielding was the only reason for a lower inactivation performance in effluent with a higher suspended solids concentration, Xu et al. (2002) filtered the effluent and found no influence on the ozone demand. Xu et al. (2002) gives suspended solids concentration below $5 \mathrm{mg} / \mathrm{L}$ as the most important design criteria for wastewater disinfection to meet stringent standards.

The surrogate virus MS2 was inactivated more than 4-5 log, representing the limit of quantification for both ozone doses. This confirms the strong virucidal efficiency of ozone as previously reported for wastewater disinfection (Paraskeva \& Graham 2002; Xu et al. 2002; Ishida et al. 2008). Despite the high virucidal efficacy of ozone, a shielding effect could also be observed for viruses by comparing the inactivation of the bacteriophage MS2 in the same effluent after media and micro-filtration (Ishida et al. 2008).

The aerobic spores of $B$. subtilis proved to be the most resistant and no significant inactivation was detected. These findings were in accordance with results obtained at an advanced oxidation plant for drinking water treatment (Sommer et al. 2004) and for Clostridium inactivation from wastewater (Xu et al. 2002). It may also indicate a poor inactivation of protozoa such as Cryptosporidium parvum oocysts at the ozone doses applied for micropollutant removal.

No significant difference between log concentration in the effluent of the two pilot plant reactors was observed. This was thought to be due to the low ozone concentration in the effluent of R1 ( 0.2 and $\left.0.9 \mathrm{mg} \mathrm{O}_{3} / \mathrm{L}\right)$ and subsequently, a low ozone dose to the second reactor. Also $\mathrm{Xu}$ et al. (2002) reported that an additional post-contactor chamber, which raised the hydraulic retention time from 2 to $10 \mathrm{~min}$, did not result in a higher inactivation performance of fecal coliforms and E. coli due to low residual ozone concentration in the additional reactor; only additional ozone injection into the second reactor would result in higher inactivation.

In Table 2 the concentrations of the bacterial indicators $E$. coli and enterococci before and after ozonation are compared to the limits of the European bathing water directive (Directive 2006/7/EC) for inland waters. After ozonation the limits for excellent water quality were met

CIWA Publishing [2013]. The definitive peer-reviewed and edited version of this article is published in Water Science \& Technology, Volume 68, Issue 2, 311-318, 2013, https://doi.org/10.2166/wst.2013.212 and is available at www.iwapublishing.com. This is the accepted version. 
for both ozone doses. With regard to the more stringet limits for coastal waters the concentrations in the ozonated effluent complied with the standards for good water quality.

The Ct-concept usually applied for drinking water disinfection is not considered appropriate for wastewater since it implies the presence of residual ozone (Janex et al. 2000; Xu et al. 2002). However, even at transferred ozone doses below the actual ozone demand of the effluent where a complete ozone consumption occurs and no residual ozone is present, an inactivation of microorganisms was reported (Janex et al. 2000; Xu et al. 2002). Moreover, process control by a residual ozone concentration is not appropriate for advanced wastewater treatment with ozone if micropollutant removal is the targeted scope. Hence, the transferred ozone dose or the specific ozone dose/consumption applied in this paper is more appropriate. After all, a comparison of different results is significantly influenced by the suspended solids in the investigated effluent.

\section{BOD experiments}

With regard to the $\mathrm{BOD}_{5}$ measurements, it could be demonstrated that a sufficiently high number of heterotrophic bacteria survive the ozone treatment (reduction between 0.7 to $2 \log$ units), see Figure 4. Hence, no pre-treatment of the sample is needed and the BOD of ozonized effluent can be measured with the commonly applied methods, i.e. by means of the manometric or the direct method (EN 1899-2).

The results of the BOD measurements over a period of 5 days demonstrated the expected increase due to the oxidation of refractory organic matter present in the wastewater treatment plant effluent. The $\mathrm{BOD}_{5}$ before and after ozonation of the effluent with $0.6-0.7 \mathrm{~g} \mathrm{O}_{3} / \mathrm{g}$ DOC is given in Figure 5. The increase averaged 15\%. Similar results were documented by Xu et al. (2002) who determined a $20 \%$ increase after ozonation for disinfection purposes. For the investigated wastewater treatment plant this increase did not result in any transgression of the emission standard

Table 3 illustrates a theoretical calculation of the impact of ozonation on the $\mathrm{BOD}_{5}$ in two model wastewater treatment plants (WWTP I and II). It could be demonstrated that the decrease in removal efficiency is not significant. Regarding the increase in concentration, however, this intrinsic effect has to be taken into account and it is necessary to assess on a case-by-case approach whether the emission standard or the good status of the receiving water becomes limiting.

\section{CONCLUSION}

The pilot plant study provided valuable information on inactivation of microorganisms for specific ozone doses recommended for micropollutant removal from tertiary effluent. The additional microbicidal benefit could be confirmed for $E$. coli, enterococci and MS 2 bacteriophage as surrogate for viruses, while the bacterial spores were not affected.

Specific ozone consumptions of $0.6-0.9 \mathrm{~g} \mathrm{O}_{3} / \mathrm{g}$ DOC are suitable to comply with the standards for good bathing water quality of the European bathing water directive for both inland and coastal waters.

However, due to the shielding effect of total suspended solids in the effluent, inactivation of the fecal bacteria was limited to a final concentration in the effluent of about $2 \mathrm{log}$. This implies the combination of ozonation with a preceding filtration step if higher microbicidal

CIWA Publishing [2013]. The definitive peer-reviewed and edited version of this article is published in Water Science \& Technology, Volume 68, Issue 2, 311-318, 2013, https://doi.org/10.2166/wst.2013.212 and is available at www.iwapublishing.com. This is the accepted version. 
performances in terms of the inactivation of bacteria or permanent stages of bacteria and protozoa (spores, cysts, oocysts) are needed.

According to our results of the dosed surrogates, viruses seem not to be a limiting factor for the application of ozone as a disinfectant.

It has to be pointed out that after disinfection measures the fecal indicator bacteria have only limited value for the assessment of the microbiological water quality because of their higher sensitivity compared to pathogens like parasites. This may lead to misinterpretation of the water safety. Therefore, alternative approaches are needed to assess the microbicidal efficacy of disinfection measures.

The developed experimental design using dosed challenge organisms under strictly controlled conditions has proven a valuable tool to measure the performance of a disinfection plant. Due to the possibility for standardization, this method can be used for optimization of the operation of a disinfection plant as well as to compare different technologies and treatment systems.

The BOD measurement was not adversely affected and hence, the standard methods can also be applied to ozonized samples.

With regard to the intrinsic effect of BOD-increase by $15-20 \%$ at $Z_{\text {spec }}$ between 0.6 and $0.7 \mathrm{~g} \mathrm{O}_{3} / \mathrm{g}$ DOC, it is necessary to assess on a case-by-case approach whether the implementation of a post-treatment step is required due to the emission standard or the receiving water quality.

\section{REFERENCES}

Almadani, A., Ayoub, M. \& Ahmed, J. H. 2000 National report on the implementation of the United Nations convention to combat desertification. Ministry of Works and Agriculture. State of Bahrain.

Anonymous (1991). Bacteriophages as model viruses in water quality controlag. Water Res. 25(5), 529-545.

Bahr, C., Ernst, M., Reemtsma, T., Heinzmann, B., Luck, F. \& Jekel, M. 2005 Pilot Scale Ozonation of Treated Municipal Effluent for Removal of Pharmaceutical Compounds and Pathogens - The Berlin Study. IOA 17th World Ozone Congress, Strasbourg.

Chrtek, S. \& Popp, W. 1991 UV disinfection of secondary effluents from sewage treatment plants. Water Sci. Technol. 24(2), 343-346.

ISO 7899-2 2000 Water Quality - Detection and Enumeration of Intestinal Enterococci - Part 2: Membrane Filtration Method. November 2000.

Directive 2006/7/EC of the European Parliament and of the Council concerning the management of bathing water quality and repealing Directive 76/160/EEC. 15 February 2006.

DIN EN 1899-2 1998 Water Quality - Determination of Biochemical Oxygen Demand after n Days (BODn) Part 2: Method for Undiluted Samples (ISO 5815:1989 modified). May 1998.

Facile, N., Barbeau, B., Prévost, M. \& Koudjonou, B. 2000 Evaluating bacterial aerobic spores as a surrogate for Giardia and Cryptosporidium inactivation by ozone. Water Res. 34(12), 3238-3246.

Gerrity, D., Gamage, S., Holady, J. C., Mawhinney, D. B., Quiñones, O., Trenholm, R. A. \& Snyder, S. A. 2011 Pilot-scale evaluation of ozone and biological activated carbon for trace organic contaminant mitigation and disinfection. Water Res. 45(5), 2155-2165.

Gruenebaum, T., Jardin, N. \& Thoele, D. 2011 Large-Scale Treatment of Micropollutants at the Schwerte WWTP of Ruhrverband. 11th IWA Specialised Conference on Design, Operation and Economics of Large Wastewater Treatment Plants, 4-8 September, 2011, Budapest, Hungary.

Hollender, J., Zimmermann, S. G., Koepke, S., Krauss, M., McArdell, C. S., Ort, C., Singer, H., von Gunten, U. \& Siegrist, H. 2009 Elimination of organic micropollutants in a municipal wastewater treatment plant upgraded with a full-scale post-ozonation followed by sand filtration. Environ. Sci. Technol. 43(20), 7862-7869.

CIWA Publishing [2013]. The definitive peer-reviewed and edited version of this article is published in Water Science \& Technology, Volume 68, Issue 2, 311-318, 2013, https://doi.org/10.2166/wst.2013.212 and is available at www.iwapublishing.com. This is the accepted version. 
Ishida, C., Salveson, A., Robinson, K. \& Bowman, R. 2008 Ozone disinfection with the HiPOX ${ }^{\mathrm{TM}}$ reactor: streamlining an "old technology" for wastewater reuse. Water Sci. Tech. 58(9), 1765-1773.

ISO 62221999 Water Quality - Enumeration of Culturable Micro-organisms - Colony Count by Inoculation in a Nutrient Agar Culture Medium. July 1999.

ISO 930831998 Water Quality - Detection and Enumeration of Escherichia coli and Coliform Bacteria - Part 3: Miniaturized Method (Most Probable Number) for the Detection and Enumeration of E. coli in Surface and Waste Water. July 1999.

ISO 10705-1 2001 Water Quality - Detection and Enumeration of Bacteriophages - Part 1: Enumeration of Fspecific RNA Bacteriophages. January 2002.

Janex, M. L., Savoye, P., Roustan, M., Do-Quang, Z., Lainé, J. M. \& Lazarova, V. 2000 Wastewater disinfection by ozone: influence of water quality and kinetics modeling. Ozone Sci. Eng. 22(2), 113-121.

Loeb, B. L., Thompson, C. M., Drago, J., Takahara, H. \& Baig, S. (2012). Worldwide ozone capacity for treatment of drinking water and wastewater: a review. Ozone Sci. Eng. 34(1), 64-77.

Martinez, S. B., Perez-Parra, J. \& Suay, R. 2011 Use of ozone in wastewater treatment to produce water suitable for irrigation. Water Resour. Man. 25(9), 2109-2124.

Oneby, M. A., Bromley, C. O., Borchardt, J. H. \& Harrison, D. S. 2010 Ozone treatment of secondary effluent at U.S. municipal wastewater treatment plants. Ozone Sci. Eng. 32(1), 43-55.

Paraskeva, P. \& Graham, N. J. D. 2002 Ozonation of municipal wastewater effluents. Water Environ. Res. 74(6), 569-580.

Rice, R. G., Evison, L. M. \& Robson, C. M. 1981. Ozone disinfection of municipal wastewater - current state-ofthe-art. Ozone Sci. Eng. 3(4), 239-272.

Schaar, H., Clara, M., Gans, O. \& Kreuzinger, N. 2010 Micropollutant removal during biological wastewater treatment and a subsequent ozonation step. Environ. Pollut. 158(5), 1399-1404.

Sommer, R. \& Cabaj, A. 1993 Evaluation of the efficiency of a UV plant for drinking water disinfection. Water Sci. Technol. 27(3-4), 357-362.

Uhlmann, D. \& Horn, W. 2001 Hydrobiologie der Binnengewässer. Eugen Ulmer. Stuttgart, Germany.

UNEP \& GEC 2005 Water and Wastewater Reuse: An Environmentally Sound Approach for Sustainable Urban Water Management. United Nations Environment Programme, Division of Technology, Industry and Economics - International Environmental Technology Centre. Osaka, Japan.

WHO 2006a WHO Guidelines for the Safe Use of Wastewater, Excreta and Greywater. Volume 2 - Wastewater Use in Agriculture. WHO, Geneva.

WHO 2006b WHO Guidelines for the Safe Use of Wastewater, Excreta and Greywater. Volume 3 - Wastewater and Excreta Use in Aquaculture. WHO, Geneva.

Wiesmann, U., Choi, I. S. \& Dombrowski, E.-M. 2007 Fundamentals of Biological Wastewater Treatment. WileyVCH. Weinheim, Germany.

Xu, P., Janex, M.-L., Savoye, P., Cockx, A. \& Lazarova, V. 2002 Wastewater disinfection by ozone: main parameters for process design. Water Res. 36(4), 1043-1055.

Zimmermann, S. G., Wittenwiler, M., Hollender, J., Krauss, M., Ort, C., Siegrist, H. \& von Gunten, U. 2011 Kinetic assessment and modeling of an ozonation step for full-scale municipal wastewater treatment: Micropollutant oxidation, by-product formation and disinfection. Water Res. 45(2), 605-617.

First received 10 November 2012; accepted in revised form 19 February 2013

CIWA Publishing [2013]. The definitive peer-reviewed and edited version of this article is published in Water Science \& Technology, Volume 68, Issue 2, 311-318, 2013, https://doi.org/10.2166/wst.2013.212 and is available at www.iwapublishing.com. This is the accepted version. 


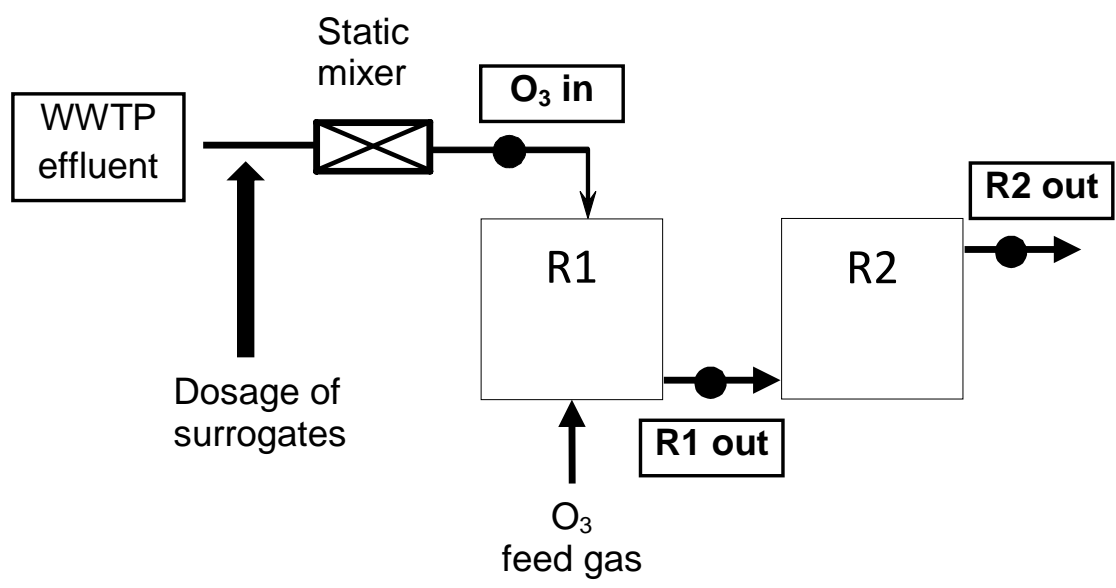

Figure 1 | Schematic diagram of the experimental set-up. Sampling ports are marked with a dot $\left(\mathrm{O}_{3}\right.$ in - influent ozonation plant, R1 out - effluent of the first pilot plant reactor, R2 out - effluent of the second pilot plant reactor, corresponding to the effluent of the pilot plant).

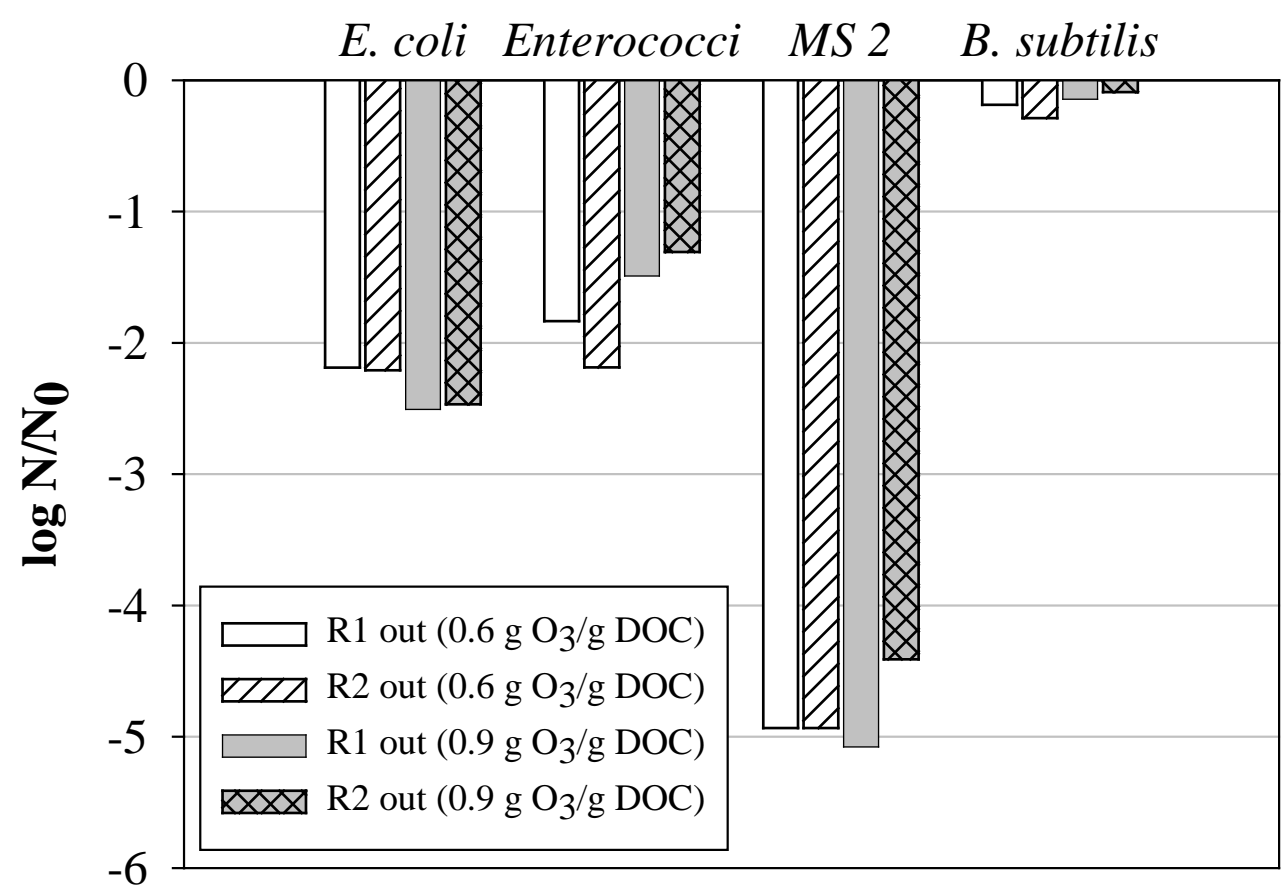

Figure 2 | Log-reduction of the indigenous bacterial indicators E. coli and enterococci and the proportionally added bacteriophage MS2 and $B$. subtilis spores at a specific ozone consumption of 0.6 and $0.9 \mathrm{~g} \mathrm{O}_{3} / \mathrm{g}$ DOC (bars represent the mean of triplicates).

CIWA Publishing [2013]. The definitive peer-reviewed and edited version of this article is published in Water Science \& Technology, Volume 68, Issue 2, 311-318, 2013, https://doi.org/10.2166/wst.2013.212 and is available at www.iwapublishing.com. This is the accepted version. 

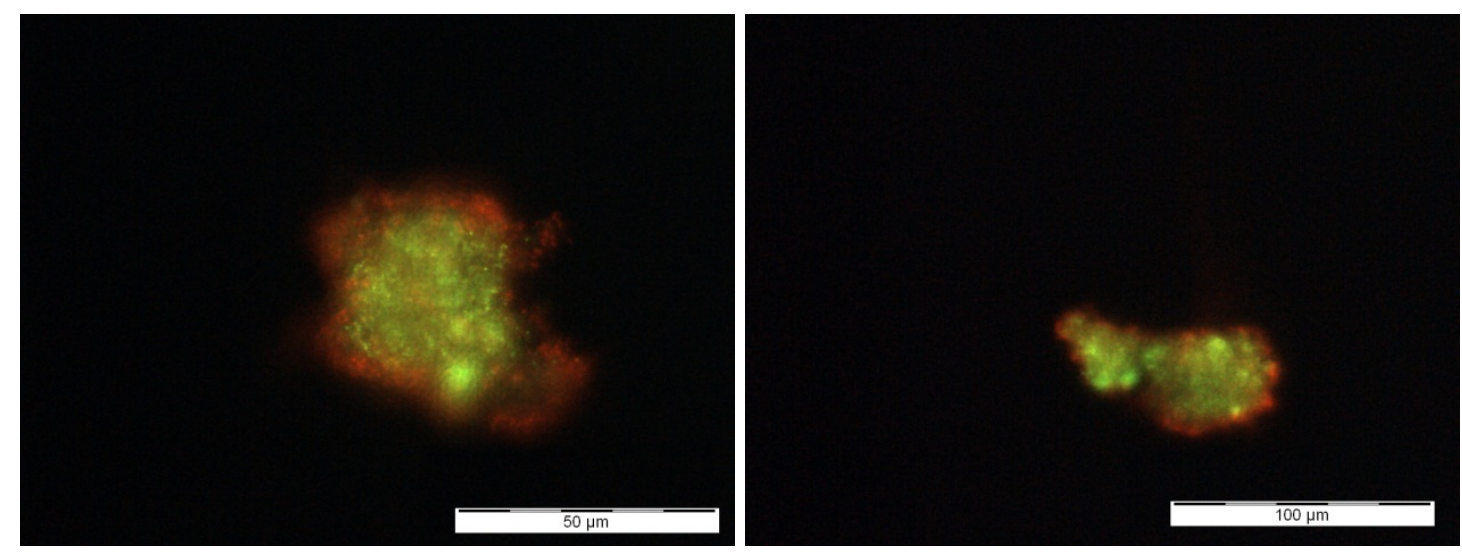

Figure 3 | Microscopic picture of the Life/Dead staining of suspended solids particles.

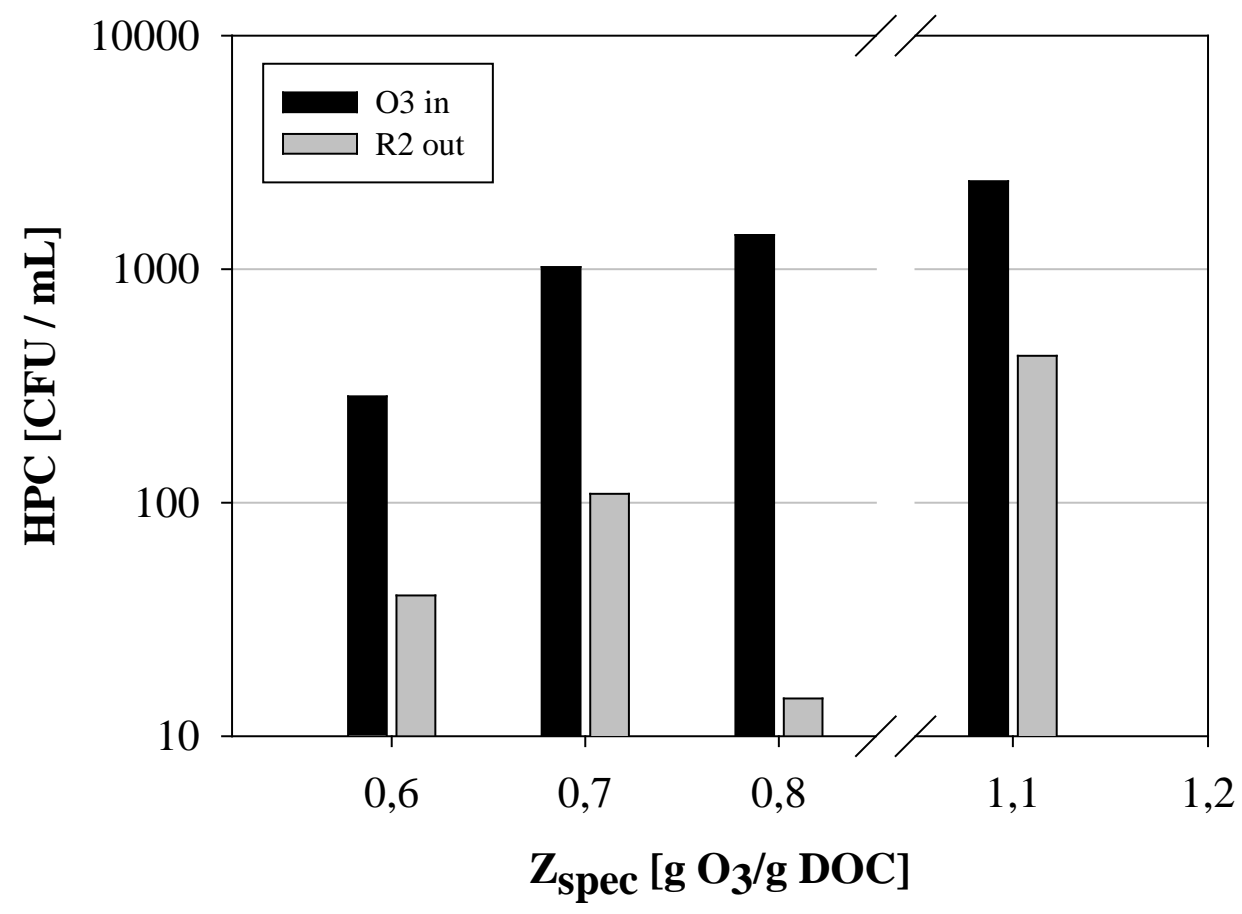

Figure 4 | Heterotrophic plate counts (HPC) in the influent $\left(\mathrm{O}_{3}\right.$ in) and in the effluent (R2 out) of the ozonation plant at various specific ozone consumptions.

CIWA Publishing [2013]. The definitive peer-reviewed and edited version of this article is published in Water Science \& Technology, Volume 68, Issue 2, 311-318, 2013, https://doi.org/10.2166/wst.2013.212 and is available at www.iwapublishing.com. This is the accepted version. 


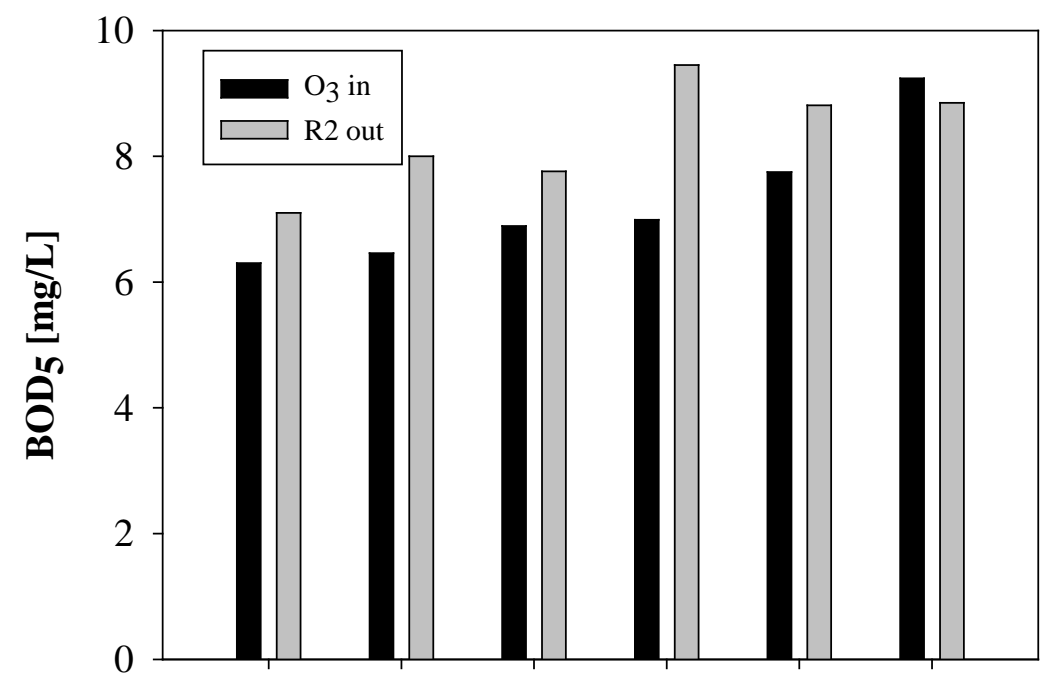

Figure 5 | $\mathrm{BOD}_{5}$ of tertiary effluent before $\left(\mathrm{O}_{3}\right.$ in) and after ( $\mathrm{R} 2$ out) ozonation at specific ozone consumptions between 0.6 and $0.7 \mathrm{~g} \mathrm{O}_{3} / \mathrm{g}$ DOC measured according to EN 1899-2.

Table 1 | Log concentrations (mean and standard deviation, SD) of the investigated microorganisms for two different specific ozone consumptions, $Z_{\text {spec }}$ (limit of quantification for bacteriophages: log 1.30)

\begin{tabular}{|c|c|c|c|c|c|}
\hline \multirow{3}{*}{ Test organisms } & \multirow{3}{*}{$\begin{array}{l}Z_{\text {spec }} \\
\begin{array}{l}\text { Sampling } \\
\text { point }\end{array}\end{array}$} & \multirow{2}{*}{\multicolumn{2}{|c|}{$\frac{0.6 \mathrm{~g} \mathrm{O}_{3} / \mathrm{g} \mathrm{DOC}}{\log \text { conc } / 100 \mathrm{~mL}}$}} & \multirow{2}{*}{\multicolumn{2}{|c|}{$\frac{0.9 \mathrm{~g} \mathrm{O}_{3} / \mathrm{g} \mathrm{DOC}}{\log \text { conc } / 100 \mathrm{~mL}}$}} \\
\hline & & & & & \\
\hline & & Mean & SD & Mean & SD \\
\hline \multirow{3}{*}{$\begin{array}{l}\text { Escherichia coli } \\
\text { (MPN /100 mL) }\end{array}$} & O3 in & 4.64 & 0.13 & 4.30 & 0.01 \\
\hline & R1 out & 2.45 & 0.05 & 1.79 & 0.17 \\
\hline & R2 out & 2.43 & 0.03 & 1.83 & 0.10 \\
\hline \multirow{3}{*}{$\begin{array}{l}\text { Enterococci } \\
\text { (MPN / } 100 \mathrm{~mL})\end{array}$} & O3 in & 4.11 & 0.10 & 3.65 & 0.14 \\
\hline & R1 out & 2.27 & 0.12 & 2.16 & 0.25 \\
\hline & R2 out & 1.92 & 0.05 & 2.34 & 0.06 \\
\hline \multirow{3}{*}{$\begin{array}{l}\text { B. subtilis spores } \\
\text { (CFU / } 100 \mathrm{~mL} \text { ) }\end{array}$} & O3 in & 5.88 & 0.06 & 5.91 & 0.03 \\
\hline & R1 out & 5.69 & 0.01 & 5.76 & 0.05 \\
\hline & R2 out & 5.59 & 0.02 & 5.82 & 0.03 \\
\hline \multirow{3}{*}{$\begin{array}{l}\text { Bakteriophagen MS2 } \\
\text { (PFU / mL) }\end{array}$} & O3 in & 4.93 & 0.02 & 5.08 & 0.06 \\
\hline & R1 out & $<1.30$ & - & $<1.30$ & - \\
\hline & R2 out & $<1.30$ & - & 0.67 & 0.58 \\
\hline
\end{tabular}

CIWA Publishing [2013]. The definitive peer-reviewed and edited version of this article is published in Water Science \& Technology, Volume 68, Issue 2, 311-318, 2013, https://doi.org/10.2166/wst.2013.212 and is available at www.iwapublishing.com. This is the accepted version. 
Table 2 | Concentration of intestinal enterococci and $E$. coli in the effluent before $\left(\mathrm{O}_{3}\right.$ in) and after ozonation (R2 out) in comparison to the limits of the European bathing water directive for two different specific ozone consumptions

\begin{tabular}{|c|c|c|c|c|c|}
\hline \multirow{2}{*}{$\begin{array}{l}\text { Parameter according to } \\
\text { directive } 2006 / 7 / E G\end{array}$} & \multicolumn{3}{|c|}{ Quality (inland waters) } & \multirow{2}{*}{03 in } & \multirow{2}{*}{03 in } \\
\hline & excellent & good & sufficient & & \\
\hline $\begin{array}{l}\text { Intestinal enterococci } \\
\text { (cfu/100 ml) }\end{array}$ & $200 *$ & $400^{*}$ & $330 * *$ & 12876 & 4235 \\
\hline $\begin{array}{l}\text { Escherichia coli } \\
(\mathrm{cfu} / 100 \mathrm{ml})\end{array}$ & $500 *$ & $1000^{*}$ & $900 * *$ & 43064 & 18684 \\
\hline \multirow{3}{*}{$\begin{array}{l}\text { Parameter according to } \\
\text { directive } 2006 / 7 / \mathrm{EG}\end{array}$} & & & & R2 out & R2 out \\
\hline & & & & $\mathrm{Z}_{\text {spec }}=0.6$ & $\mathrm{Z}_{\mathrm{spec}}=0.9$ \\
\hline & excellent & good & sufficient & $\mathrm{g} \mathrm{O}_{3} / \mathrm{g} \mathrm{DOC}$ & $\mathrm{g} \mathrm{O}_{3} / \mathrm{g} \mathrm{DOC}$ \\
\hline $\begin{array}{l}\text { Intestinal enterococci } \\
(\mathrm{cfu} / 100 \mathrm{ml})\end{array}$ & $200 *$ & $400 *$ & $330 * *$ & 94 & 196 \\
\hline $\begin{array}{l}\text { Escherichia coli } \\
(\mathrm{cfu} / 100 \mathrm{ml})\end{array}$ & $500 *$ & $1000^{*}$ & $900 * *$ & 240 & 78 \\
\hline
\end{tabular}

* based on 95-percentile evaluation

** based on 90-percentile evaluation

Table 3 | BOD removal of two model WWTPs with a projected BOD 5 increase of 15 and $20 \%$ after ozonation

\begin{tabular}{|c|c|c|c|c|c|c|c|}
\hline & $\begin{array}{l}\text { WWTP } \\
\text { influent }\end{array}$ & effluent & eta BOD $_{5}$ & $\begin{array}{c}\text { O3 out } \\
(+15 \% \\
\left.\text { BOD }_{5}\right)\end{array}$ & $\begin{array}{c}\text { eta } \\
\text { BOD }_{5}\end{array}$ & $\begin{array}{c}\text { O3 out } \\
(+20 \% \\
\left.\text { BOD }_{5}\right)\end{array}$ & eta $\mathrm{BOD}_{5}$ \\
\hline & mg/L & $\mathrm{mg} / \mathrm{L}$ & $\%$ & $\mathrm{mg} / \mathrm{l}$ & $\%$ & $\mathrm{mg} / \mathrm{l}$ & $\%$ \\
\hline WWTP I & 300 & 5 & 98.3 & 5.75 & 98.1 & 6 & 98.0 \\
\hline WWTP II & 300 & 8 & 97.3 & 9.2 & 96.9 & 9.6 & 96.8 \\
\hline
\end{tabular}

CIWA Publishing [2013]. The definitive peer-reviewed and edited version of this article is published in Water Science \& Technology, Volume 68, Issue 2, 311-318, 2013, https://doi.org/10.2166/wst.2013.212 and is available at www.iwapublishing.com. This is the accepted version. 